\title{
Concept: Using E-Learning Platforms in Economical and Entrepreneurial Development
}

\author{
Cătălin Ionuț SILVESTRU ${ }^{1}$, Ioana BURCEZAN (PRECUP) ${ }^{1}$, Ramona Camelia BERE ${ }^{1}$, \\ Marian Ernuț LUPESCU ${ }^{2}$ \\ ${ }^{1}$ Bucharest University of Economic Studies, Romania, \\ ${ }^{2}$ National Qualification Authority, Bucharest, Romania \\ catalin@ase.ro,im.precup@gmail.com,ramona.bere@gmail.com, ernut.lupescu@gmail.com
}

Business failure is an intrinsic characteristic of entrepreneurship. Given its dimension and repercussions, we consider that entrepreneurial education, in particular entrepreneurial $e$ learning platforms should include a module on business failure covering in addition to the national legal framework and EU policies, the key barriers faced by entrepreneurs and causes of business failure and other such elements. Thus, we propose to develop a platform based on open source software, such as Moodle in which modules based on SCORM and interactive teaching have been developed, with all the tools that are needed to simulate classic teaching.

Keywords: Business failure, Bankruptcy, e-Learning Platforms, Moodle, Learning Objects

1 Introduction

SMEs are the backbone of the European Union economy, according to the "Annual report on small and medium-sized enterprises in the EU, 2011/12" [1] they account in 2012 for more than $98 \%$ of total enterprises active in the European Union. Moreover, SMEs contribute to almost $60 \%$ of gross added value and ensure up to $67 \%$ of jobs. Considering the aforesaid and the Europe 2020 strategy for smart, sustainable and inclusive growth, entrepreneurship plays a key role. Thus, for achieving these, three areas of intervention have been considered in the Entrepreneurship 2020 Action Plan [2] as follows: extending entrepreneurial education and training; encouraging business formation by providing a supportive business environment, promoting new business formation and fostering an entrepreneurial culture.

In this context and as a continuity of the Lisbon Strategy, business failure, defined in this paper as bankruptcy or business closure, is considered to be a key aspect as it entails stigma of failure, which represents a barrier in creating a supportive entrepreneurial environment. Therefore, in order to encourage entrepreneurship at EU level it is important to raise awareness that failure represents a learning opportunity for entrepreneurs. Bankruptcy is a burden on business owners, and alongside the legal and financial burden, hangs stigmatization by the business community and society in general. One cause of stigma is associating business failure with fraud [2].

Offering a second chance to honest entrepreneurs who have gone through bankruptcy, implies more efficient use of available resources, higher growth rates of business and a lower probability of failure due to their experience as entrepreneurs [9].

These entrepreneurs can be considered as resource, considering the Entrepreneurship 2020 Action Plan, and it is essential not to lose such a resource by not giving them a second chance to overcome stigma, while concentrating only on "nurturing the new generation of entrepreneurs" [2].

Moreover, it is important to emphasize that despite the negative impact that business failure has at a social level [3], psychological level [4][5] and on the business environment [3], business failure is also linked to economic growth and to progress [6][7].

Business failure is a natural event through which entrepreneurs who do not have the ability to optimize the use of resources exit the market. An inefficient business provides certain warning signs, however it depends on the ability of management to perceive these signals and react in time to redress the 
business. Otherwise, it can lead to business failure and transfer of resources towards more productive activities. McKenzie \& Lee [8] state that failure, as business closure, is both an output for unsuccessful enterprises and an input of economic success. Economic growth and long-term progress are not possible without encouraging business growth and innovation.

Taking into account the need to learn about entrepreneurship and business management including business failure, we propose the development of an e-learning module on business failure, while also considering the fact that the advantages of e-learning platforms outweigh their disadvantages. Potential beneficiaries of such platform could be either MSc students. The choice of MSc students as target group is determined by more focused interest on learning about specific topics, in contrast with the broader, more general focus in the BSc level. Moreover, we consider that such a course could be of use, and as such, provided also to entrepreneurs, as part of lifelong learning programs.

\section{Concept of the E-Learning Module on Business Failure}

The e-learning module on business failure is to be integrated in a broader e-learning course dedicated to entrepreneurial education and training. It aims to provide students with information on the national legal framework and EU policies, the key barriers faced by entrepreneurs and causes of business failure, the economic impact, social and psychological impact, debt management, and business failure risk assessment. We consider that acknowledging the causes leading to bankruptcy and a thorough understanding of the impact of business failure will contribute to early detection/prevention of failure risk. Hence, the training module will be designed for students so as to achieve the following objectives:

1. To understand the role, legal framework of insolvency procedure and which steps to undergo if one has to open the insolvency procedure. Both globally and in
Europe the insolvency laws are quite heterogeneous. "There is a bankruptcy law that is Pareto-optimal" [11]. Differences arise from the existence of several types of insolvency law codes: British, German, French and Scandinavian. These disparities make it difficult to develop a single global legislation or at European level.

Thus, for national level, specific legal framework should be covered, taking into account the domestic specificities. We consider that in the case of Romania, the Insolvency Law No. 85/2006 [12] should be discussed. Within this law, insolvency is defined as a two-state situation: bankruptcy or business closure and reorganization. At EU level, the Entrepreneurship 2020 Action Plan [2] should be covered, together with the communication of the European Commission - A new European approach to business failure and insolvency [13]. As legal framework develops in time, further updates should be made regularly, in order to include these updates, even possible changes in approaches to business failure and insolvency.

2. To acknowledge the causes of business failure. As defined by Ooghe and Waeyaert [10], these refer to immediate environment, general environment, management/entrepreneur, corporate policy or to company's characteristics. The causes of business failure might be related to micro environment of the enterprise or to macro environment (at a national, regional or global level). For better understanding of their impact, the causes that refer to the above-mentioned aspects (immediate environment, general environment, etc.) should be addressed separately.

3. To raise awareness on the legal, economic, social and psychological impact of bankruptcy, so as to contribute to reducing the financial loss generated by business failure. The legal and economic impacts are going to be addressed in conjunction to the above-mentioned. 
The social and psychological impacts will be highlighted based on extensive literature review.

4. To provide information on debt management so as to emphasize its benefits and to raise awareness on how advisory services can help entrepreneurs in distress manage their debt and overcome the crisis they face. We take into account to include this aspect in the training course, due to the fact that the European Commission invites Member States to provide active support to business in distress.

5. To provide information on business failure risk assessment. This would focus mainly on presenting early warning indicators highlighting financial distress. The methodology proposed for choosing the indicators to be included in the course content will consider a vast literature review of studies analyzing financial ratios as the predictors of business failure from which the indicators most relevant will be taken into account.

In order to ensure practical learning of students and understanding the impact of financial ratio on business efficiency, some models assessing the prediction power of financial ratios will be included on the online platform. The models proposed use various prediction techniques: robust logistic regression [14], discriminant analysis [15] [16], data development analysis and multi-layer perception [17], neural networks [18], hazard models [19] [21], logistic models [19][20][21] and Bayesian models [19] [22]. More models will be grounded based on extensive literature review and the study developed by Bellovary, Giacomino and Akers [22].

However, the models considered can vary according to the literature that will be evaluated and to the ranking of the models by their effectiveness in predicting bankruptcy. The structure of the training module will correspond to the above-mentioned objectives. In addition to the training materials (online documents and videos), for each module, additional resources will be provided, such as literature reviews, links to statistics on business demographics.

Within the platform, the module regarding bankruptcy will be a pilot one, aiming to provide a dynamic program in entrepreneurial education. The disciplines provided have a dynamic content generated in function of the results obtained during the tests conducted during learning. Thus, the tests are structured so as to indicate the acquired theoretical and practical abilities and the path the student should take further with regard to the acquired study materials.

We intend to develop an interactive training module based on an exploratory and interactive learning approach by integrating in the learning process group works, case studies and scenario simulation. Online class room meetings using video chat will be held and an online information timetable, an online library and a forum will be provided. [23]

The training course will not be focused only on theory, but will also include practical applications, interactive learning and online mentoring. On the long run, we also take into consideration the networking dimension between students outside the training course and will encourage them to organize offline meetings or / and form offline social clubs, so as to discuss with entrepreneurs that have experienced bankruptcy and have started fresh afterwards.

Such a module is taken into account to be developed within one of the MSc programs within Bucharest University of Economic Studies, as part of program intended for further development of the existing e-learning platforms. One of the platforms that is taken into account for this module is formare.contatic.ase.ro, an e-learning platform that is used for training entrepreneurs, students and other people that are interested in entrepreneurial domains and financial domains.

\section{The E-Learning Platform Module}

The platform that will use the module for entrepreneurial use, such as business failure, will be based on Moodle, using the SCORM 
system which contains the tools and resources required for sustaining the main actors of the educational system - students, instructors, experts and managers throughout the course presentation. Choosing Moodle is based on its functions that allow, although this defines a basic e-learning platform structure, as seen in Figure 1:

- A teacher to create teaching activities for groups, instructional multimedia resources and its own monitoring tools for monitoring student activities;

- A student to consult recommended teaching materials and online resources or to download these materials, it gives him the possibility to organize these materials and the resources by observing the evolution of his own learning process, it offers solutions to problems and exercises;

- Some students and designated monitors to communicate, suggest topics for debates and to collaborate;

- A platform administrator to install the learning system and to assure its maintenance, to administer the access rights of the users and to create links that lead to external informational systems.

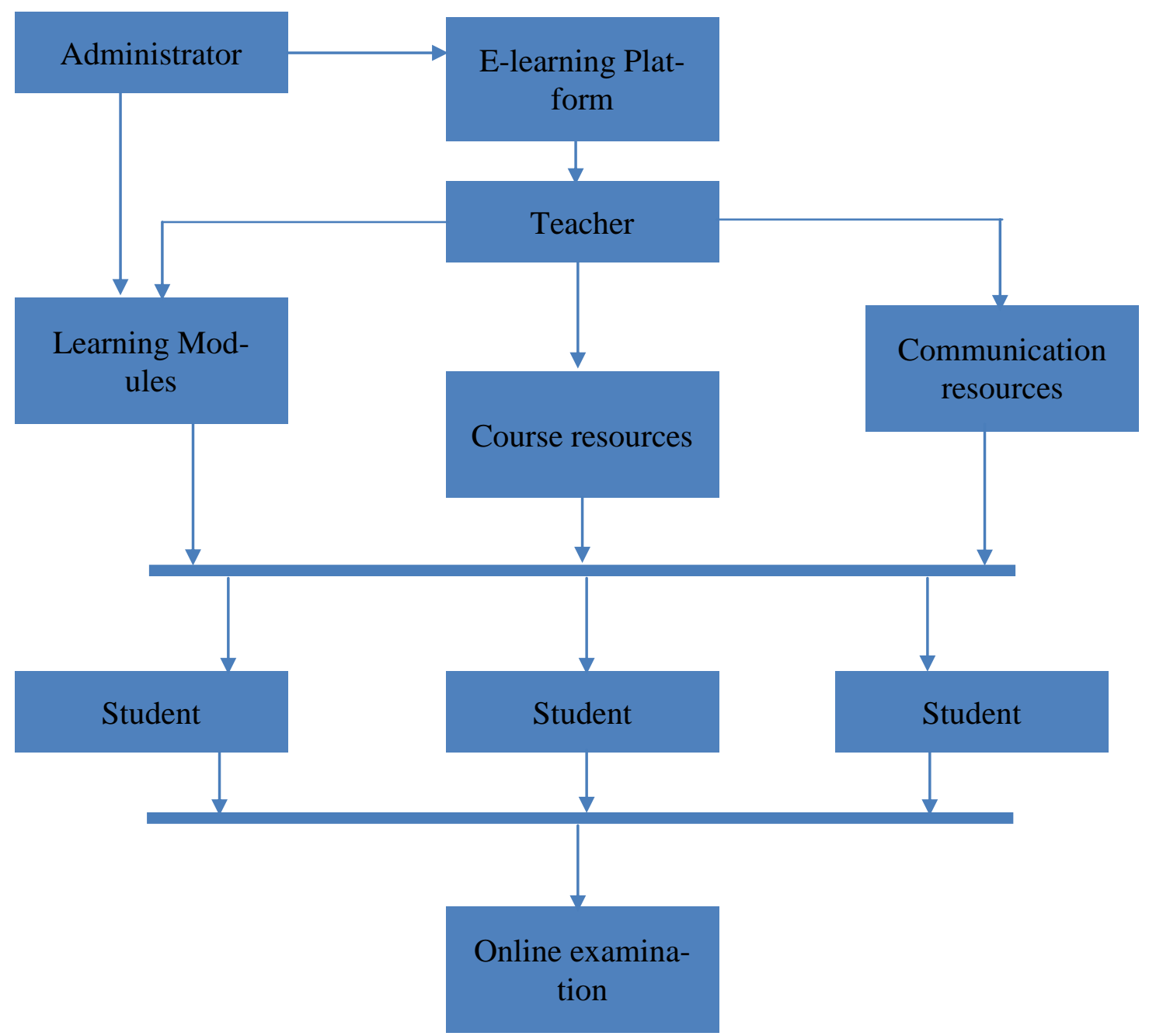

Fig. 1. Basic e-learning platform structure

Such an approach could lead to a curricular definition of e-learning: an extension of the traditional learning system. Since the main concept of a global informational system is represented by an application seen as a con- cept, as the foundation stone for e-learning platforms, assisted training can be defined as a social application of the global informational system that offers educational services, as long as training can be integrated 
as a component of the cognitive domain using dedicated software [24]. Although Moodle can be used as such a software through courses and modules designed especially for such a purpose, its main utility is that it can be used without teacher intervention other than that described above.

The students can engage in a dialogue, with the possibility of interrupting and redirecting the information flow, they can modify its complexity, the speed at which it is communicated and the manner in which it is presented. They can control elements of the multi-sensorial experiences, combining audio, video and text with graphic ones into one reality.

Libraries, through a proper adaptation, have become key elements of informational highways, through the digitization, organizing and distribution of electronic information, reaching as far as delivering it through local networks, regional networks and World Wide Web.

The approach regarding the development of the e-learning platform, both the architecture and also the elements that relate to the teaching and evaluation process, will be a multidimensional approach as can be seen in Figure 2.

The standard that will be used is that of SCORM because the learning management system defined by it can be divided into LCMS (Learning Content Management Solutions) and LMS (Learning Managements System). The learning content management system is a multi-user environment, where content developers can create, store, reuse, administrate and supply digital learning content. LMS manages the activities around the learning process and LCMS creates and supplies the learning content.

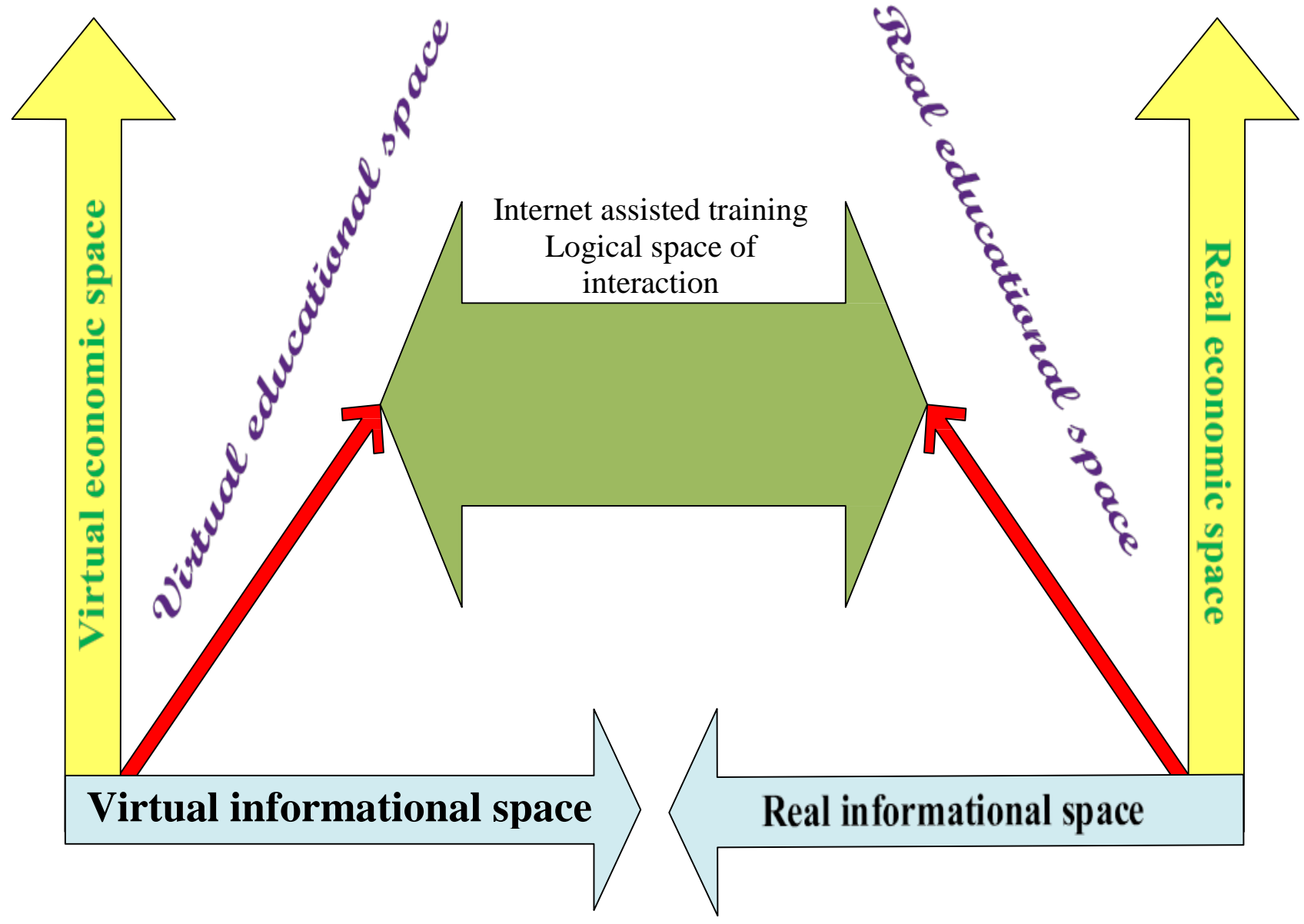

Fig. 2. E-learning platforms: a multidimensional approach on internet assisted training 
LCMS allows the users to create and reuse small units of digital educational content, which in our case enables reuse of content related to insolvency in other educational program on entrepreneurship, on business development / management. The use of structured learning metadata standards and also the import/export format standards allow learning objects to be created and used in common with multiple learning programs, applications and content repositories, thus enabling the development of specialized content repositories, which in our case means development of content repositories on entrepreneurship, business development / management.

Moreover, creation of learning objects enables easier updating of content, e.g. in the case of stages in the development of EU legal framework, based on updates and changes in approaches related to insolvency, so as to understand the role of insolvency in the business cycle and the causes of business failure. In addition, practical applications could be easier developed and further included in e-learning module, covering aspects related to variations / changes in content, as previously mentioned and as result of students' suggestions, provided that the joint work of teachers, students and platform administrators could be ensured.

Rather than creating a specifically designed e-learning platform for business failure, bankruptcy and entrepreneurial failure related domains, we considered that a module for an existing platform/platforms would better suit the needs of entrepreneurs and teachers alike.

As mentioned before, we are considering implementing such a module on the elearning platform formare.contatic.ase.ro. This platform is based on training people in entrepreneurial domains, in financial domains, in how to make use of entrepreneuri- al tools. Implementing a module in a platform that is related already with entrepreneurs, but which lacks the debates, tools and courses for business failure, entrepreneurial failure, which does not currently have interactive courses for these topics, in our opinion, will bring a benefits to students.

Students can learn the basics of being an entrepreneur, of starting their business, of consolidating their business, but when this module will be added, they could also learn how to better protect their business from bankruptcy and how to avoid business failure. The module, as described in the beginning, with the use of interactive tools and even offline meetings and events that will be scheduled in a meeting calendar that will be included in the module, can also help entrepreneurs that have face business failure, bankruptcy and could not find the means to inform themselves on the matter at hand.

Also they, in our opinion, will have a better chance at getting back on the market, making use of the information from the module with regard to the legal framework available and the examples of entrepreneurs that have been through bankruptcy and managed to raise a new business again. Such information can also be shared on the module's forum, and not only through general information that is posted through the platform, getting students and entrepreneurs to get in touch with one another and having debates around how successful entrepreneurs managed to get rid of the stigma regarding business failure.

The structure of the e-learning platform and that of the module will be modified to be implemented with m-learning [25], due to the fact that m-learning is a part of elearning, as shown in figure 2, bringing the information required by students in a faster and easier manner to access through such implementation. 


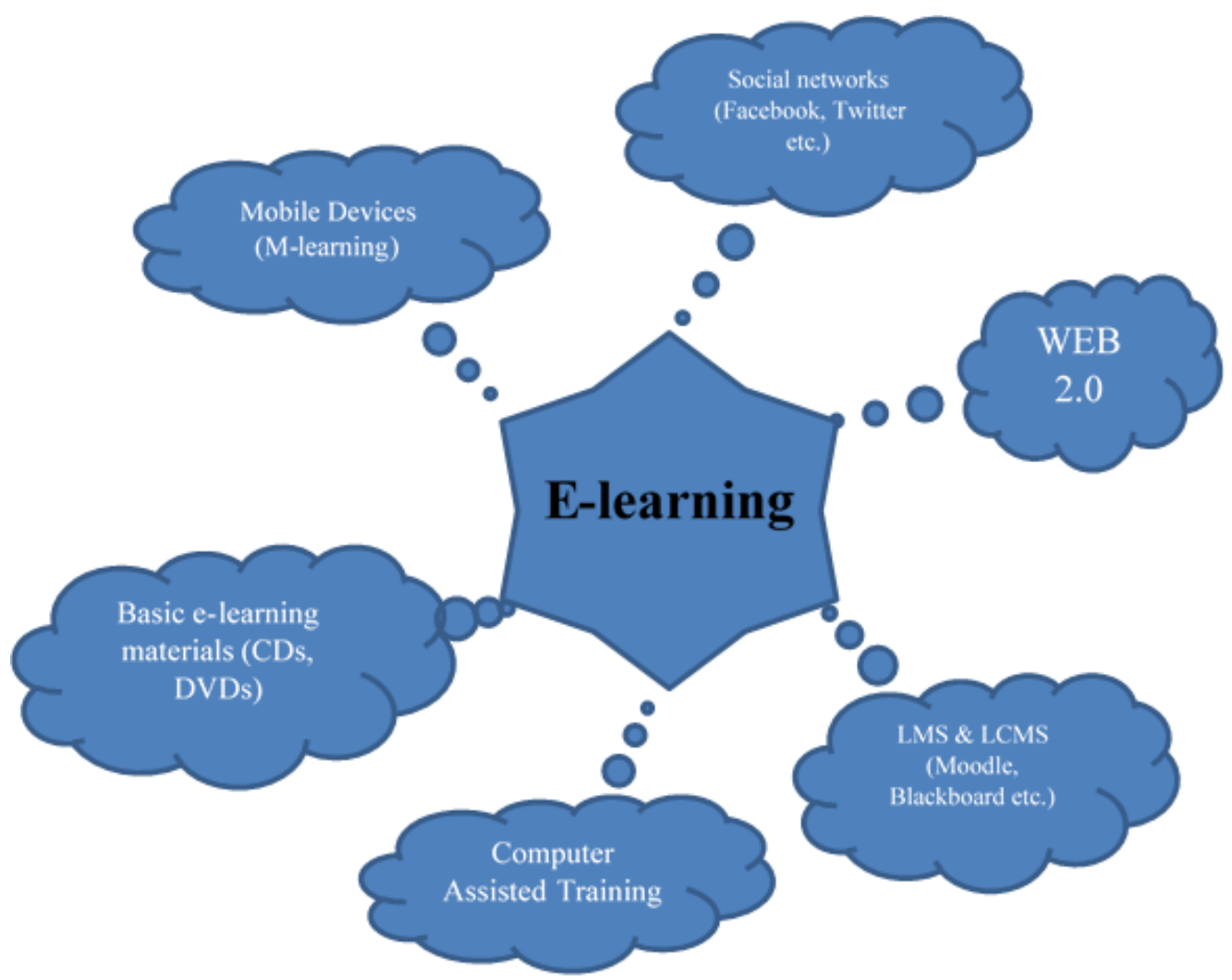

Fig. 3. Basic components of e-learning

Implementing the e-learning module in such a manner as to allow mobile applications to connect to it via Web-Services, XML or other ways that make live exchanges of information between the mobile application (Android, Windows Mobile, iOS or other) will benefit both the students and the tutors. Some of the benefits [26] of approaching elearning through m-learning are:

1. Ease of access - With the use of mobile devices more and more in society, starting with smartphones, phablets, tablets and other devices that allow internet connectivity, information is passed on faster than it used to through the help of laptops, thus students can check their learning materials on the go or even take exams via an application that is installed on the device, or straight through the handheld device's internet browser. Both of these manners of examination are in reach and can be easily implemented for mobile devices;

2. Cost reduction - through the use of mobile devices instead of personal computers or laptops, the cost derived from the use of an e-learning platform is reduced.
This cost, although not high even in conventional e-learning methods, is further reduced due to the low prices of smartphones and tablets and through the possibility of using mobile carriers for mobile internet, or even free hotspots available;

3. Asynchronous learning - the use of mobile devices helps with delivering information to students in an asynchronous manner.

There are also some downsides of managing the module in a manner that makes it usable just for mobile devices, for m-learning. Some of these disadvantages are:

1. Battery life - The battery life a mobile devices varies from device to device, but essentially it is short in comparison with a personal computer. To make it more difficult, an m-learning initiative requires that the devices to be connected to either a wireless network or a mobile data network, both consuming a big part of the battery;

2. Screen size - Although mobile devices are becoming more and more utilized in everyday life, the fact remains that the 
screen sizes of these devices are not well suited for reading a lot of information. Though, a workaround this problem would be recorded voice courses, or podcasts;

3. Device diversity [27] - due to the fact that there are multiple sized mobile devices on different mobile platforms (Windows Mobile, Android, iOS and others), the work required to make modules or e-learning platforms easily integrated on every device is a difficult task. These are just a few of the advantages and disadvantages of developing the e-learning platform/module in a manner that can be easily integrated with m-learning.

The reason why we consider that implementing the module for the e-learning platform should also take into consideration mlearning is derived from the fact that mobile devices are starting to be used more and more for other educational related purposes. Although the knowledge obtained through the use of these devices is that of nonformal learning, the fact remains that it was obtained through the use of such technology.

Mobile devices are starting to be used in a more interactive manner in e-learning, having modules and teaching materials developed especially for such devices. Even elearning platforms are starting to develop their design so that the content that is shown, at a student user level, can be seen in a manner that is appealing and easy to use on mobile devices through the use of their built-in browsers or other third party applications.

\section{Conclusions and Future Work}

Our current society is characterized through a growing rate of change that is seen in both on physical aspects and in a logical one: concepts converge to form new concepts that better suit a new society, individuals converge into virtual communities, either local or global, based on their interests, and professional skills converge towards the defining of new professions. Technology, as an infrastructure for researching activities, converges towards the creation of new technologies.

The use of an e-learning platform, as a means to deal with the problems like bankruptcy and entrepreneurial failure; to teach entrepreneurs more about the legislation that affects them on a national or on an European level; to teach them how to better use the information at hand, how other entrepreneurs dealt with bankruptcy; is something that is needed in our information based society where time is also a resource. Entrepreneurs cannot afford to lose neither one of these resources when dealing with such problems.

By using the advantages that e-learning platforms bring in education in general, such as mobility, ease of use, accessibility, we will bring an efficient means to enriching the knowledge base of entrepreneurs that want to learn about the risks of business failure, teaching entrepreneurs that have gone through such problems how to get back on the market with their business or just making them aware of the implications, good and bad ones, of starting their business.

Such an e-learning platform will bring information that is useful in a fast and efficient manner to entrepreneurs. We argue this due to the fact that, as mentioned earlier, our society is characterized through a high and fast rate of change, which applies not only to technology, but also to every other aspect of society, and in our case legal matters, entrepreneurial studies, research on the matter at hand etc. Having such information structured in a manner that is molded for e-learning platforms will make it easier and faster for entrepreneurs to grasp every change that is related to relevant aspects in their domain.

Also, taking into account the fact that society is getting more and more accustomed with mobile devices and with the exchange of information that comes with the use of such devices, we consider that it is important to keep developing the module and the platform in such a manner that allows it to be used on mobile devices. 
Keeping e-learning platforms confined to personal computers and laptops is no longer an option in today's society where information exchange happens more often through the use of social media, web 2.0 which in turn are accessed and used by mobile devices, either smartphones, tablets, phablets or other such devices.

We consider that, through the use of such an e-learning platform, that keeps up with the changes in society, with the changes that affect business, entrepreneurs, legal matters and many other related domains, entrepreneurs that went through business failure might get a second chance at building a long lasting business that complies with the Europe 2020 strategy.

As result of learning about business failure, entrepreneurs will have acquired knowledge to deal with such an issue, by making use of existing e-learning technological resources.

\section{Acknowledgement}

„This paper was co-financed from the European Social Fund, through the Sectorial Operational Programme Human Resources Development 2007-2013, project number POSDRU/159/1.5/S/138907 "Excellence in scientific interdisciplinary research, doctoral and postdoctoral, in the economic, social and medical fields -EXCELIS", coordinator The Bucharest University of Economic Studies".

\section{References}

[1] ECORYS, EU SMEs in 2012: at the crossroads - Annual report on small and medium-sized enterprises in the EU, 2011/12, Rotterdam, September 2012 http://ec.europa.eu/enterprise/policies/sm e/facts-figures-analysis/performance- review/files/supportingdocuments/2012/annual-report_en.pdf

[2] *** Entrepreneurship 2020 Action Plan, Reigniting the entrepreneurial spirit in Europe $\operatorname{COM}(2012) 795$ final, Brussels, 2013 http://eurlex.europa.eu/LexUriServ/LexUriServ.do ?uri=COM:2012:0795:FIN:EN:PDF
[3] Silvanavičiũte, S., Estimating the Negative Impact of Business Failure on Lithuania, Social Research, Nr. 4 (14), 113120 , 2008

http://vddb.library.lt/fedora/get/LT-

eLABa-0001:J.04 2008 ISSN_1392-

3110.N_4_14.PG_113119/DS.002.1.01.ARTIC

[4] Cope, J., Entrepreneurial learning from failure: An interpretative phenomenological analysis, J. of Bus. Venturing (2010), doi:10.1016/j.jbusvent.2010.06.002 http://www.dge.ubi.pt/msilva/Papers_M ECE/Paper_5.pdf

[5] Singh, S., Corner, P., Pavlovich, K., Coping with entrepreneurial failure, Journal of Management \& Organization, Vol. 13, Issue 4, 331-344, 2007

[6] Jackson, T., Skeel, D., Bankruptcy and Economic Recovery, http://www.nomurafoundation.or.jp/data /20121026_David_Skeel- Thomas_Jackson_000.pdf

[7] Cox, M., Alm, R., Creative Destruction, The Concise Encyclopaedia of Economics, February 2012, http://www.econlib.org/library/Enc/Crea tiveDestruction.html

[8] McKenzie, Richard B.\& Lee, Dwight R., Failure and Progress -The bright Side of the Dismal Science, Washington , D.C., 2003

[9] *** A Second Chance for Entrepreneurs: Prevention of Bankruptcy, Simplification Of Bankruptcy Procedures And Support For A Fresh Start, Brussels, 2011

[10] H. Ooghe, S. De Prijcker, "Failure processes and causes of company bankruptcy: a typology," Management Decision, Vol 46, Issue 2, 2004, 223 242, Emerald Group Publishing Limited

[11] D. Dăianu, D. Pîslaru, L. Voinea, "Studiul nr. 8 - Aspecte ale Falimentului în Economia Românească," Institutul European din România, Bucureşti, 2004

[12]*** Romanian Insolvency Law no. $85 / 2006$, with modifications and amendments 
[13] *** A new European approach to business failure and insolvency $\operatorname{COM}(2012)$,final 742

[14] R.P. Hauser, D. Booth, "Predicting Bankruptcy with Robust Logistic Regression," Journal of Data Science 9, 565584, 2011

[15] E.I. Altman, "Financial ratios, discriminant analysis and the prediction of corporate bankruptcy," Journal of Finance 23(4), 589-609, 1968

[16] O. Hajdu,M. Virág, "Hungarian Model For Predicting Financial Bankruptcy," Society and the Economy in Central and Eastern Europe, vol. 23. No. 1-2., 2846, 2001

[17] A. Ayan Mukhopadhyay, S. Tiwari, A. Narsaria, B.R. Karmake, "A New Approach to Predicting Bankruptcy: Combining DEA and Multi-Layer Perceptron," International Journal of Computer Science Issues, Vol. 9, Iss. 4, No 2, 7178, 2012

[18] P. du Jardin, "Predicting bankruptcy using neural networks and other classification methods: the influence of variable selection techniques on model accuracy," Neurocomputing, Vol. 73, No. 1012, pp. 2047-2060, 2010

[19] A. Chaudhuri, "Bankruptcy Prediction Using Bayesian, Hazard, Mixed Logit and Rough Bayesian Models: A Comparative Analysis," Computer and Information Science, Vol. 6, No. 2, 2013

[20] M.H. Keener, "Predicting the Financial Failure of Retail Companies In The
United States," Journal of Business \& Economics Research, Vol. 11, No. 8, 373-380, 2013

[21] B.P. Foster, J. Zurada, "Loan defaults and hazard models for bankruptcy prediction," Managerial Auditing Journal, Vol. 28, pp. 526-542, 2013

[22] J. Bellovary, D. Giacomino, M. Akers, "A Review of Bankruptcy Prediction Studies: 1930 to Present," Journal of Financial Education, Vol. 33, 1-43, 2007

[23] M. Diaconu; I. Jinga, Pedagogie, http://www.biblioteca- digitala. ase.ro/biblioteca/carte2.asp?id=387\&i $\mathrm{db}=24$

[24] I. G. Roşca, B. Ghilic-Micu, M. Stoica, Informatica. Societatea informaţională. E-serviciile, 2006

[25] A. Tugrul Korucu, A. Alkan, "Differences between m-learning (mobile learning) and e-learning, basic terminology and usage of m-learning in education," Procedia social and behavioral sciences 15, 2011, 1925-1930

[26] N. Ciftci Ozuorcun, F. Tabak, "Is Mlearning versus E-learning or are they supporting each other?," Procedia social and behavioral sciences 46, 2012, 299305

[27] Y. Alioon, O. Delialioglu, "A frame for the literature on m-learning," Procedia social and behavioral sciences 182, 2015, $127-135$

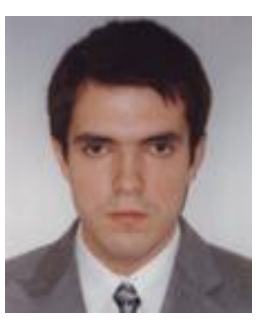

Cătălin Ionuț SILVESTRU is assistant professor in Economic Informatics and Cybernetics Department, Academy of Economic Studies of Bucharest. He published over 52 articles in journals and magazines in computer science, informatics, e-learning, project management and long life learning fields, over 30 papers presented at national and international conferences, symposiums and work-shops and he was member over thirty-eight research projects. $\mathrm{He}$ is coauthor of four books. He received his $\mathrm{PhD}$ in the field of Economic Informatics at the Academy of Economic Studies. He is a member of INFOREC professional association, Project Management Romania association, ACM, IEEE and others. He has one invention and one prototype approved. His work focuses on the programming, information system, e-learning, long life learning, project management and Human Resources Development. 


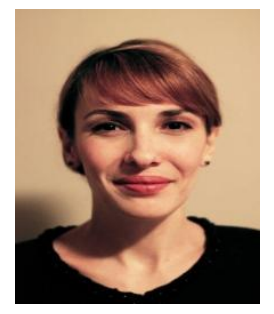

Ioana BURCEZAN (PRECUP) is PhD student in Statistics Department, Academy of Economic Studies of Bucharest. She presented over 5 papers presented at international conferences, symposiums and workshops. Her work focuses on business demographics, business failure, project evaluation and monitoring.

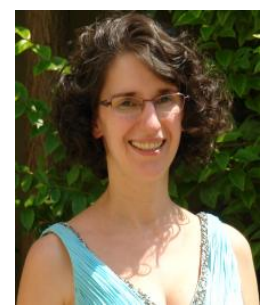

Ramona Camelia BERE is PhD student in Statistics Department, Academy of Economic Studies of Bucharest. She published articles in journals and magazines in public administration, computer science, informatics, elearning, project management and long life learning fields, over 10 papers presented at international conferences, symposiums and work-shops and she was member two research projects. She is a member of ACM professional association. Her work focuses on public policies, urban and regional development, public administration, human resource development, e-learning, long life learning and project management.

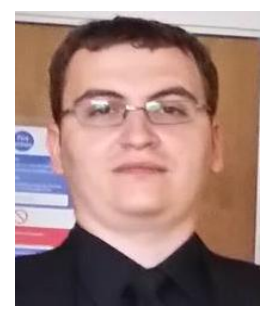

Marian Ernuț LUPESCU is currently working at National Authority for Qualifications in Romania. He published and presented 3 articles in journals and international conferences. His work focuses on the programming, information system, e-learning, long life learning, qualifications, computer science and lifelong learning. 